\title{
An Improved Chemically Defined Medium for Mass Cultures of Tetrahymena: Nutrient Uptake and Growth Regulation
}

\author{
By CONJEEVARAM E. SRIPATI \\ Institut de Biologie Physico-chimique, 13 rue Pierre et Marie Curie, F-75005 Paris, France
}

(Received 8 January 1987; revised 15 April 1987)

\begin{abstract}
A chemically defined medium for growing mass cultures of Tetrahymena was developed. The growth characteristics and the effects of variations in the culture conditions and medium constituents were studied. The results show that Tetrahymena can be grown in a completely defined medium with rates and yields nearly comparable to those obtained in non-defined media. In the defined medium, $\mathrm{K}^{+}$but not $\mathrm{Na}^{+}$, was indispensable for growth; unlike in media containing proteose peptone, the growth rate was independent of the presence of insoluble $\mathrm{Fe}^{3+}$ complexes, but was more dependent on culture temperature. Although Tetrahymena has an absolute requirement for preformed purine and pyrimidine bases in addition to several amino acids, its proliferation and growth were primarily under amino acid control.
\end{abstract}

\section{INTRODUCTION}

The ciliate protozoan Tetrahymena is currently receiving much attention (Gall, 1984), mainly because it offers several interesting features among which are its highly specific nutritional requirements (Holz, 1973) and the organization (Gorovsky, 1980) and function of its genome, in particular the ribosomal RNA genes (Engberg, 1985; Hufschmid, 1985). In its natural environment, Tetrahymena feeds phagotropically on bacteria, yeasts and other particulate nutrients (Elliott, 1959; Holz, 1973). In the laboratory, however, controlled experimental conditions require cells grown in axenic and completely soluble media. Several such media have been developed, the most successful being those that contain proteinaceous complexes, liver or yeast-extract, and salts (Everhart, 1972). However, these non-defined media are not suitable for biochemical experiments which require efficient labelling of macromolecules and manipulation of the cell's nutritional environment. Therefore, the development of a chemically defined minimal medium capable of supporting reproducible growth with high yields is of great interest.

Kidder \& Dewey (1951) were the first to develop a defined medium that was later revised by Elliott et al. (1954); however, these media gave poor generation times and final yields. Holz et al. $(1959,1962)$ introduced important modifications which significantly improved the medium but yields remained low and the growth pattern was often irreproducible. A variant of this medium was described by Rasmussen \& Modweg-Hansen (1973). Since then these media have not been optimized nor have the parameters of growth of Tetrahymena in them been established.

In this paper a systematic study of the medium developed by Holz et al. (1962) is described.

\section{METHODS}

Chemicals. Guanosine, Tween 80, folinic acid calcium salt and L-amino acids, except methionine, were Sigma grade from Sigma. L-Methionine (A-grade) was from Calbiochem. Folic acid, pyridoxamin. $\mathrm{HCl}$, water-free glucose, citric acid and other salts were 'pro analysi'-grade from Merck. Biotin was obtained from Hoffmann-La Roche; DL-6,8-thioctic acid and riboflavin 5'-phosphate sodium salt were from Serva; other vitamins were from Fluka. ${ }^{14} \mathrm{C}$-Labelled compounds were from CEA.

Abbreviation: LDS, lithium dodecylsulphate. 
Strains. Amicronucleate strains T. elliotti (CCAP 1630/Id) and T. pyriformis (CCAP 1630/Iz) were obtained from the Culture Collection of Algae and Protozoa, Ambleside, UK. The micronucleate T. thermophila strains BIV 1868 and BVII 1868 were a generous gift from Dr Nanney, Department of Zoology, University of Urbana, Illinois 1801, USA.

Preparation of stock solutions. The components and their concentrations in the stock solutions and in the final medium are listed in Table 1. Glass-distilled water was used throughout. The $\mathrm{pH}$ of the stock solutions of all amino acids was adjusted to 6.8 with dilute $\mathrm{HCl}$ or with $\mathrm{KOH}$ if the mixture contained free glutamic acid in place of monosodium glutamate. Amino acid and Tween solutions were filter-sterilized (0.22 $\mu \mathrm{m}$ Swinnex; Millipore). Folic acid was dissolved by adding a few drops of a dilute solution of $\mathrm{K}_{2} \mathrm{CO}_{3}$; a working solution $\left(5 \mu \mathrm{g} \mathrm{ml}^{-1}\right)$ was prepared by further dilution and was filter-sterilized. Thioctic acid solution was prepared in absolute ethanol and a working solution $\left(5 \mu \mathrm{g} \mathrm{ml}^{-1}\right)$ was made by further dilution in $25 \%(\mathrm{v} / \mathrm{v})$ ethanol. Glucose solutions were filtered $(0.45 \mu \mathrm{m}$; Millipore) to remove particulate impurities; uracil and guanosine were dissolved by adding a few drops of $2 \mathrm{M}-\mathrm{KOH}$; these solutions were autoclaved at 110 or $120^{\circ} \mathrm{C}$ for 20 to $30 \mathrm{~min}$. A $500 \times$ stock solution of a mixture of all the trace elements was adjusted to $\mathrm{pH} 2$ with concentrated $\mathrm{HCl}$. All solutions except glucose, uracil and guanosine were stored protected from light at $-20^{\circ} \mathrm{C}$. Soluble $\mathrm{Fe}^{3+}$ was a filter-sterilized solution containing $5 \mathrm{mg}$ $\mathrm{FeCl}_{3} \cdot 6 \mathrm{H}_{2} \mathrm{O} \mathrm{ml}^{-1}$. Insoluble $\mathrm{Fe}^{3+}$ was prepared as described by Rasmussen et al. (1985).

Preparation of media. Standard defined medium. For preparing 1 litre of standard medium, the appropriate amounts of each of the inorganic salts and citric acid (Table 1) were dissolved in a small amount of water potassium phosphate and magnesium sulphate separately, citric acid and calcium carbonate together, and uracil and guanosine together (by addition of a few drops of $\mathrm{KOH}$ ). Appropriate portions of the vitamin stock solutions (except folic acid) were mixed in about $10 \mathrm{ml}$ water. Each of these solutions was transferred, with stirring, in the following order to about $200 \mathrm{ml}$ water (for medium without amino acids) or of a solution containing all the amino acids except methionine, tryptophan or any other amino acid to be omitted from the medium: citric acid and calcium carbonate, uracil and guanosine, vitamin mixture, $5 \mathrm{ml}$ portion of the trace-element stock solution, magnesium sulphate and finally potassium phosphate. The $\mathrm{pH}$ was adjusted to 6.8 with $10 \mathrm{M}-\mathrm{KOH}$ and the volume brought to $500 \mathrm{ml} ; 25$ to $100 \mathrm{ml}$ portions were autoclaved at $120^{\circ} \mathrm{C}$ for $20 \mathrm{~min}$ in screw-capped bottles wrapped in aluminium foil and stored between 5 and $10^{\circ} \mathrm{C}$. This is the standard double-strength basal medium; it is stable for more than 1 year. At the time of setting up cultures, appropriate amounts of the stock solutions of amino acids, folic acid, glucose and Tween were added, and the medium was brought to the final volume with sterile (autoclaved) water.

Non-defined media. Proteose peptone yeast-extract (PPY) and proteose peptone (PP) media were prepared as described previously (Hjelm, 1970; Everhart, 1972; Cuny et al., 1985).

Culture conditions. Stock cultures. The different strains of Tetrahymena were maintained at $20^{\circ} \mathrm{C}$ as continuously growing stock cultures by frequent subculturing in PP medium in capped tubes.

Experimental cultures. Cultures were grown, unless specified otherwise, at $31{ }^{\circ} \mathrm{C}$ in subdued light on a gyratory shaker ( 90 r.p.m.) in Erlenmeyer flasks of capacity 10 times the volume of culture. Pre-cultures were grown in the respective medium (PPY or defined) to a density of about $8 \times 10^{5}$ cells $\mathrm{ml}^{-1}$ and the working cultures, usually 50 to $200 \mathrm{ml}$, were seeded with these cells to an initial density of 0.5 to $1.0 \times 10^{3}$ cells ml-1. Cells were counted in a Coulter counter model $\mathrm{F}$.

Determination of protein, RNA and DNA accumulation. Protein. Accumulation of protein was determined by measuring the incorporation of a labelled amino acid. At intervals, samples were transferred to tubes containing LDS $(0.1 \%$, w/v, final concentration); cells lysed immediately. After adding 1 vol. cold $20 \%$ (w/v) TCA and mixing, samples were left at $4{ }^{\circ} \mathrm{C}$ for $1 \mathrm{~h}$, then heated for $30 \mathrm{~min}$ in a water-bath at $90^{\circ} \mathrm{C}$ and cooled; the protein precipitate from each sample was collected on a Millipore filter and washed with cold $5 \%$ (w/v) TCA. The filters were dried and their radioactivity was determined in a toluene-based scintillation mixture.

RNA and DNA. Almost $99 \%$ of uracil incorporated by Tetrahymena is in RNA and DNA; therefore, the accumulation of RNA during culture growth was measured directly in a small number of cells as the radioactivity incorporated from $\left[2-{ }^{-14} \mathrm{C}\right]$ uracil which was continuously present in the culture; at various intervals, two samples were withdrawn and transferred to tubes, one containing LDS $(0.1 \%$, w/v, final concentration) and the other an equal volume of $0.6 \mathrm{M}-\mathrm{KOH}$. The cells lysed immediately in both tubes. The $\mathrm{KOH}$-treated sample was kept at $37^{\circ} \mathrm{C}$ for $10 \mathrm{~h}$, for alkaline hydrolysis of RNA. The LDS-treated sample was immediately mixed with 1 vol. cold $20 \%(\mathrm{w} / \mathrm{v}) \mathrm{TCA}$ and kept at $4{ }^{\circ} \mathrm{C}$ for $1 \mathrm{~h}$; the precipitate was then collected on a Millipore filter and washed with cold $5 \%(\mathrm{w} / \mathrm{v}) \mathrm{TCA}$; radioactivity was determined as for the protein samples. This represents the cold-TCAprecipitable total radioactivity in the sample.

The KOH-treated samples were cooled to $4{ }^{\circ} \mathrm{C}$ and mixed with 0.1 vol. $3 \mathrm{M}-\mathrm{HCl}$ and 1 vol. cold $20 \%$ (w/v) TCA. The precipitates formed were processed and radioactivity was measured as described above. This represents the alkali-stable, mostly DNA, radioactivity in the sample. The radioactivity of RNA in the sample was obtained by subtracting the alkali-stable radioactivity from the total TCA-precipitable radioactivity. 
Table 1. Composition of standard defined medium

The presence of D-isomers of amino acids and a mixture of all four purine and pyrimidine nucleosides or nucleotides is not only unnecessary but does not contribute to optimum growth; therefore, only L-amino acids, guanosine and uracil were included. Tween $\mathbf{8 0}$ is not essential for growth, but was added in order to prevent adherence of cells to the inner surface of acid-washed and unsiliconized glassware normally used for growing and handling cultures.

\begin{tabular}{|c|c|c|c|c|c|}
\hline Component & $\begin{array}{l}\text { Stock } \\
\text { solution } \\
\text { concn }\end{array}$ & $\begin{array}{l}\text { Final } \\
\text { medium } \\
\text { concn }\end{array}$ & Component & $\begin{array}{l}\text { Stock } \\
\text { solution } \\
\text { concn }\end{array}$ & $\begin{array}{l}\text { Final } \\
\text { medium } \\
\text { concn }\end{array}$ \\
\hline L-Amino acids & $\left(\mathrm{mg} \mathrm{ml}^{-1}\right)$ & $\left(\mathrm{mg} \mathrm{1}^{-1}\right)$ & Inorganic salts & $\left(\mathrm{mg} \mathrm{ml}^{-1}\right)$ & $\left(\mathrm{mg} \mathrm{l}^{-1}\right)$ \\
\hline $\begin{array}{l}\text { Alanine } \\
\text { Arginine } \\
\text { Asparagine- } \mathrm{H}_{2} \mathrm{O} \\
\text { Sodium glutamate } \\
\text { Glutamine }\end{array}$ & $\begin{array}{r}3 \cdot 75 \\
7 \cdot 50 \\
5 \cdot 00 \\
10 \cdot 00 \\
2 \cdot 50\end{array}$ & $\begin{array}{l}150 \\
300 \\
200 \\
400 \\
100\end{array}$ & $\begin{array}{l}\mathrm{K}_{2} \mathrm{HPO}_{4} \cdot 3 \mathrm{H}_{2} \mathrm{O} \\
\mathrm{MgSO}_{4} \cdot 7 \mathrm{H}_{2} \mathrm{O} \\
\mathrm{CaCO}_{3}\end{array}$ & & $\begin{array}{r}650 \\
500 \\
75\end{array}$ \\
\hline Glycine & $5 \cdot 00$ & 200 & $\mathrm{Fe}\left(\mathrm{NH}_{4}\right)_{2}\left(\mathrm{SO}_{4}\right)_{2} \cdot 6 \mathrm{H}_{2} \mathrm{O}$ & $2 \cdot 840$ & $14 \cdot 20$ \\
\hline Isoleucine & 5.00 & 200 & $\mathrm{ZnSO}_{4} \cdot 7 \mathrm{H}_{2} \mathrm{O}$ & 0.900 & $4 \cdot 50$ \\
\hline Leucine & $5 \cdot 00$ & 200 & $\mathrm{MnSO}_{4} \cdot 4 \mathrm{H}_{2} \mathrm{O}$ & 0.242 & $1 \cdot 21$ \\
\hline Lysine. $\mathrm{HCl}$ & $5 \cdot 00$ & 200 & $\mathrm{Co}\left(\mathrm{NO}_{3}\right)_{2} \cdot 6 \mathrm{H}_{2} \mathrm{O}$ & $0 \cdot 100$ & 0.50 \\
\hline Methionine & $2 \cdot 25$ & 90 & $\mathrm{CuSO}_{4} .5 \mathrm{H}_{2} \mathrm{O}$ & 0.060 & $0 \cdot 30$ \\
\hline $\begin{array}{l}\text { Phenylalanine } \\
\text { Proline }\end{array}$ & $\begin{array}{r}3.75 \\
5.00\end{array}$ & 150 & $\left(\mathrm{NH}_{4}\right)_{6} \mathrm{Mo}_{7} \mathrm{O}_{24} \cdot 4 \mathrm{H}_{2} \mathrm{O}$ & 0.020 & $0 \cdot 10$ \\
\hline $\begin{array}{l}\text { Proline } \\
\text { Serine }\end{array}$ & $\begin{array}{l}5.00 \\
3.75\end{array}$ & $\begin{array}{l}200 \\
150\end{array}$ & Vitamins & & $\left(\mu \mathrm{g} \mathrm{1}^{-1}\right)$ \\
\hline Threonine & $5 \cdot 00$ & 200 & Nicotinic acid & 0.90 & 900 \\
\hline Tryptophan & 3.75 & 150 & Calcium D-pantothenate & $1 \cdot 50$ & 750 \\
\hline Valine & $3 \cdot 75$ & 150 & Sodium riboflavin 5 -phosphate & 0.90 & 450 \\
\hline Pyrimidine/purine & & & $\begin{array}{l}\text { Pyridoxal. } \mathrm{HCl} \\
\text { Pyridoxamin. } \mathrm{HCl}\end{array}$ & $\begin{array}{l}0.50 \\
0.50\end{array}$ & $\begin{array}{l}50 \\
50\end{array}$ \\
\hline $\begin{array}{l}\text { Uracil } \\
\text { Guanosine }\end{array}$ & $\begin{array}{l}12 \cdot 50 \\
20 \cdot 00\end{array}$ & $\begin{array}{r}37 \cdot 5 \\
100 \cdot 0\end{array}$ & Biotin & $\begin{array}{l}0.05 \\
1.00 \\
1.00\end{array}$ & $\begin{array}{r}1 \\
500 \\
20\end{array}$ \\
\hline Other organics & & $\left(\mathrm{g} \mathrm{l}^{-1}\right)$ & $\begin{array}{l}\text { Folic acid } \\
\text { DL-6,8-Thioctic acid }\end{array}$ & $\begin{array}{l}1.00 \\
1.00\end{array}$ & $\begin{array}{l}20 \\
20\end{array}$ \\
\hline $\begin{array}{l}\text { Glucose } \\
\text { Tween } 80 \\
\text { Citric acid }\end{array}$ & $\begin{array}{r}500 \cdot 00 \\
50 \cdot 00\end{array}$ & $\begin{array}{r}10 \cdot 0 \\
1.0 \\
0 \cdot 6\end{array}$ & & & \\
\hline
\end{tabular}

\section{RESULTS AND DISCUSSION}

\section{Growth characteristics of Tetrahymena in the standard medium}

When cells from late exponential cultures were seeded into fresh standard medium, exponential growth started immediately after seeding even with as few as 500 cells ml$^{-1}$ and ended abruptly when the maximum culture density was reached, such that the overall growth pattern was a fairly long exponential phase immediately followed by stationary phase (see Fig. $2 a$ ). There was no cell death even up to $20 \mathrm{~h}$ in the stationary phase cultures. The abrupt ending of the exponential phase was, however, the result of specific nutrient depletion (see below). A comparison of the growth rates and maximum yields in PPY and defined media showed that these parameters varied with strain as well as with the nature of the culture medium. Thus, the doubling time of the amicronucleate (pyriformis and elliotti) strains was $220 \mathrm{~min}$ in both media, but that of the micronucleate (thermophila) strains was $220 \mathrm{~min}$ in defined medium and $165 \mathrm{~min}$ in PPY medium; also, whereas the amicronucleate strains reached maximum densities of $2 \times$ $10^{6}$ and the micronucleate strains of $4.2 \times 10^{6}$ cells $\mathrm{ml}^{-1}$ in PPY medium, they both reached only about $1.2 \times 10^{6}$ cells $\mathrm{ml}^{-1}$ in defined medium. Nevertheless the values of these parameters in the defined medium represent significant improvements over those reported so far with mass cultures of Tetrahymena in similar media (Everhart, 1972). Some of the factors that affect the growth parameters in the defined medium were examined in the thermophila strain BIV. 


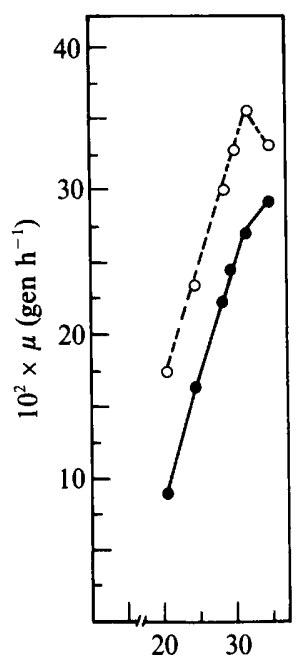

Temperature $\left({ }^{\circ} \mathrm{C}\right)$

Fig. 1

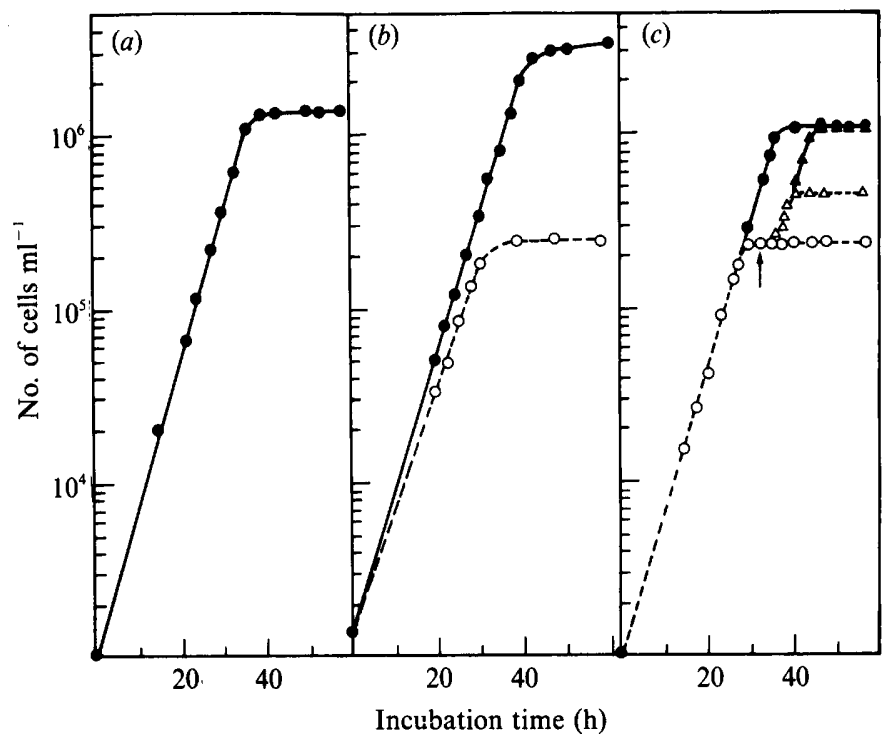

Fig. 2

Fig. 1. Population doubling time in defined and non-defined media. T. thermophila was inoculated into fresh PPY medium $(O)$ or standard defined medium $(O)$ and cultured at temperatures from 20.5 to $30.5^{\circ} \mathrm{C}$.

Fig. 2. Dependence of cell growth on the concentration of amino acids in the culture medium. $T$. thermophila was grown in $(a)$ standard medium, $(b)$ standard medium containing $0 \cdot 1$ times $(O)$ or 4 times $(O)$ the normal concentration of all the seventeen amino acids, $(c)$ standard medium with lysine initially at the normal $(O)$ or one-tenth the normal $(O)$ concentration and after restitution, at the point indicated by arrow, with either one-tenth $(\triangle)$ or nine-tenths $(\Delta)$ of the normal concentration.

\section{Effect of $\mathrm{Fe}^{3+}$ and folic and folinic acids on growth rate}

$\mathrm{Fe}^{3+}$ salts and folic and folinic acids have been shown to promote growth of Tetrahymena under different culture conditions (Rasmussen \& Kludt, 1970; Orias \& Rasmussen, 1976; SuhrJessen \& Orias, 1979). The standard medium was supplemented with $\mathrm{Fe}^{3+}$, either as soluble $\mathrm{FeCl}_{3}$ or as insoluble hydroxo- $\mathrm{Fe}^{3+}$ in colloidal or particulate form (Rasmussen et al., 1985). The doubling rate, however, remained the same whether the culture was supplemented with $\mathrm{Fe}^{3+}$ or not. Adding ferric-EDTA in place of $\mathrm{FeCl}_{3}$ also had no effect. When the culture temperature was raised from 28.5 to $31.5^{\circ} \mathrm{C}$, the doubling time decreased by about $60 \mathrm{~min}$, and the presence of $\mathrm{Fe}^{3+}$ in any form had no further influence. The iron requirement is satisfied by $36 \mu \mathrm{M}-\mathrm{Fe}$ present in the standard medium. Similarly, addition of more folic acid either alone or along with $\mathrm{Fe}^{3+}$ did not alter the doubling rate significantly. Either folic or folinic acid at a concentration of $45 \mathrm{nM}$ can support normal growth; increasing the concentration of folic acid alone or in the presence of folinic acid did not improve the growth rate.

\section{Effect of temperature on growth rate in the non-defined and defined media}

The number of cell divisions per hour $(\mu)$ was determined as a function of culture temperature for the thermophila strains. Results in Fig. 1 (a) show that, at $20.5^{\circ} \mathrm{C}$ (the minimum temperature tested) $\mu$ was higher in PPY medium than in defined medium and, as the temperature was raised, $\mu$ increased in both media; however, beyond $31.5^{\circ} \mathrm{C}$, it declined in PPY medium but continued to increase, though at a slower rate, in defined medium. The maximum culture yield nevertheless remained the same at all temperatures tested (not shown). Thus, as has been reported for different strains of Tetrahymena in various media (Everhart, 1972, Cameron, 1973), temperature stimulated the growth rate in both defined and non-defined media. The degree of stimulation, however, was significantly higher in the defined medium. 


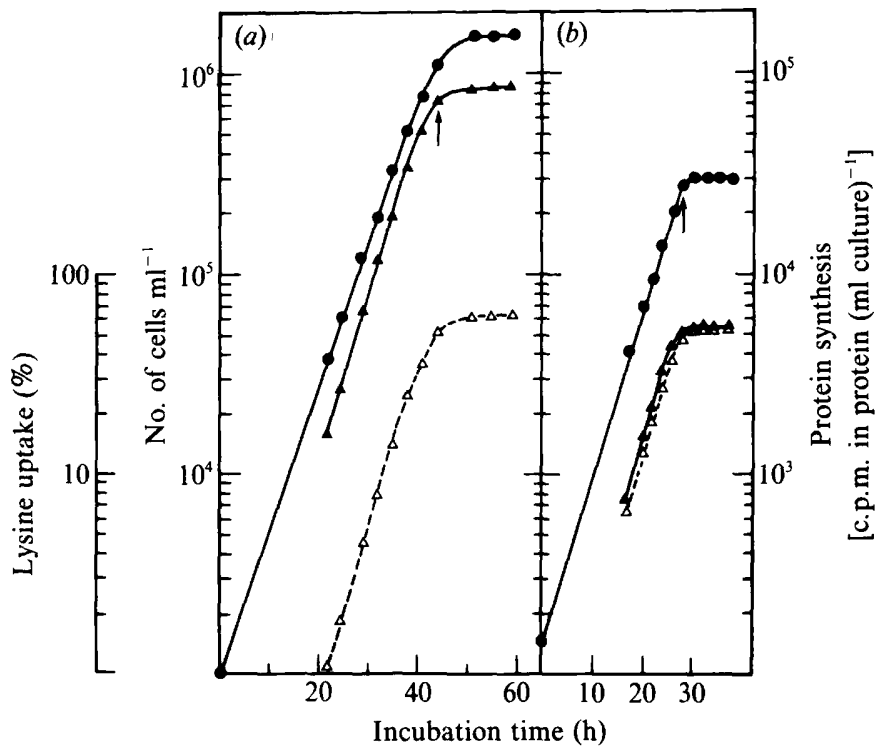

Fig. 3. Relation between cell growth and the concentration of a single essential amino acid in the culture medium. T. thermophila was cultured in defined medium containing $\mathrm{L}-\left[\mathrm{U}-{ }^{14} \mathrm{C}\right] \mathrm{lysine}[2 \cdot 35 \mathrm{kBq}$ $\mathrm{ml}^{-1}(a)$ or $\left.1.97 \mathrm{kBq} \mathrm{ml}^{-1}(b)\right]$. No. of cells; $\boldsymbol{\Lambda}$, net protein synthesis $\left(\left[{ }^{14} \mathrm{C}\right]\right.$ lysine incorporated into protein); $\triangle$, lysine uptake (percentage of the initial amount). (a) Standard medium with normal concentration of lysine $\left(1.37 \mu \mathrm{mol} \mathrm{ml} l^{-1}\right) ;(b) 0.178 \mu \mathrm{mol}$ lysine $\mathrm{ml}^{-1}$. Arrow indicates culture stage corresponding to cessation of net protein synthesis.

\section{Growth response to variations in concentration of the essential components in standard defined medium}

When the initial concentration of vitamins, guanosine, uracil and glucose was increased or more of these components added, either individually or collectively, to a culture that had ceased growing, there was no change, but, when the concentration of the amino acids was varied, there was a profound effect. Thus, addition of a mixture of amino acids to a culture that had entered stationary phase in the standard medium led to resumption of cellular proliferation within $2 \mathrm{~h}$ (not shown). The standard medium is therefore limiting specifically in the essential amino acids. A fourfold increase in the initial concentration of all the amino acids resulted in a slight decrease in the doubling time but caused a substantial rise in the maximum population density (Fig. $2 a, b$ ) which reached about 3.6 to $4 \times 10^{6}$ cells ml-1 instead of $1.2 \times 10^{6}$ cells ml $^{-1}$ in unsupplemented standard medium, a value as high as that in PPY medium; a tenfold decrease, however, resulted in a prompt cessation of growth at $2 \times 10^{5}$ cells $\mathrm{ml}^{-1}$ (Fig. $2 b$ ). A similar growth response was also observed when the concentration of a single essential amino acid was reduced (Fig. $2 c$ ). Thus, on reduction of the amount of lysine to one-tenth its normal concentration, the doubling rate was unaltered but cellular proliferation ceased as soon as the culture reached $2 \times 10^{5}$ cells $\mathrm{ml}^{-1}$; when the same amount of lysine was added at this stage, growth resumed but ceased again after just one more doubling of the population; if instead, the full complement of lysine was restored, the culture reached the same final density as in the complete medium (Fig. $2 c$ ). Similar results were also observed with other essential amino acids tested, e.g. valine, threonine, methionine and phenylalanine. Interestingly, as shown in Figs. $3(a, b)$ and $4(a)$, cell proliferation as well as net accumulation of RNA always ceased as soon as a little over $50 \%$ of the initial concentration of the essential amino acid had been consumed. Therefore, the abrupt cessation of growth cannot be attributed to complete depletion of amino acids.

Growth was controlled by the presence of amino acids, since cell proliferation was relatively insensitive to variation in the concentration of uracil or guanosine, even though the organism has an absolute requirement for these nucleic acid precursors. When growth ceased in standard 


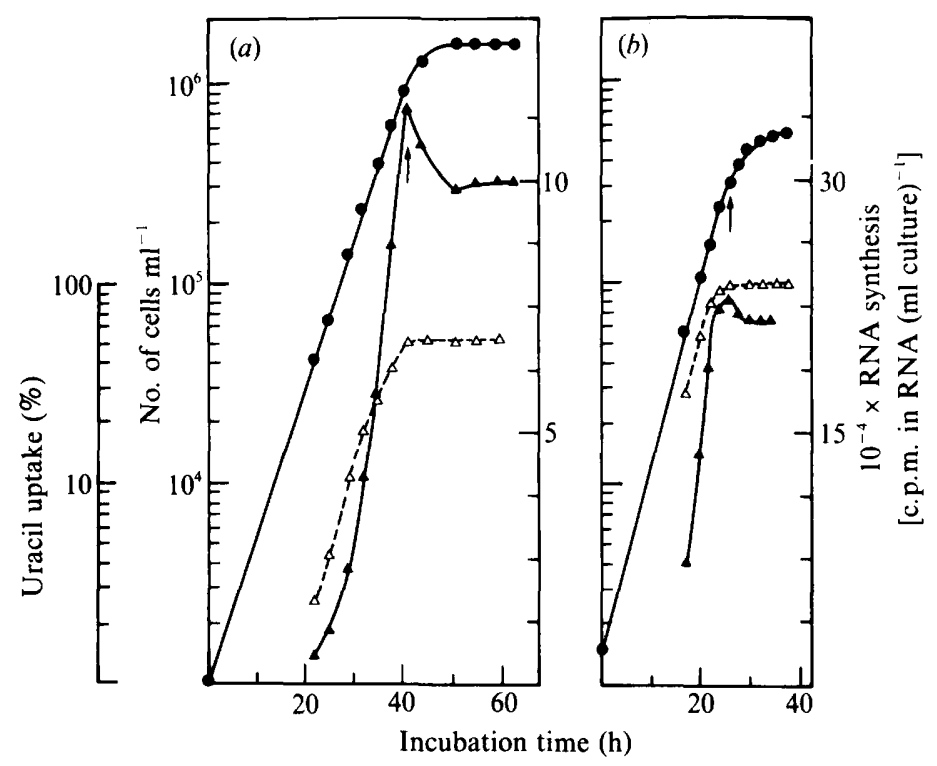

Fig. 4. Relation between cell growth and the pyrimidine concentration in the culture medium. $T$. thermophila was grown in the standard defined medium containing $\left[2 \cdot{ }^{14} \mathrm{C}\right]$ uracil $\left.(3.7 \mathrm{kBq} \mathrm{ml})^{-1}\right)$. $\bigcirc$, No. of cells; $\boldsymbol{\Delta}$, net accumulation of RNA $\left(\left[{ }^{14} \mathrm{C}\right]\right.$ uracil incorporated into total RNA); $\triangle$, uracil uptake (percentage of the initial amount of uracil consumed). (a) Standard medium with normal concentration of uracil $\left(335 \mu \mathrm{mol} \mathrm{m} l^{-1}\right)$; (b) $45 \mu \mathrm{mol}$ uracil ml-1. Arrow indicates culture stage corresponding to cessation of uracil uptake and net RNA synthesis in $(a)$, and to total depletion of uracil and arrest of RNA accumulation in $(b)$.

medium, because the amount of amino acids became inadequate, the medium still contained almost $50 \%$ of the initial amount of uracil (Fig. $4 a$ ). But, if the initial concentration of uracil had been reduced so that it became limiting before that of the amino acids, the cells grew normally and consumed all the uracil; then, only net accumulation of RNA ceased but both protein accumulation and cellular proliferation continued through almost two generations in the absence of uracil (Fig. $4 b$ ). This is not surprising since exponentially growing cells, when shifted to a pyrimidine-free medium, can continue to grow and divide more than twice in $24 \mathrm{~h}$ (Cameron, 1965).

\section{Effect of $\mathrm{Na}^{+}, \mathrm{K}^{+}$and Tris on cell growth}

The standard medium designed for optimum growth contained $2.4 \mathrm{mM}-\mathrm{Na}^{+}$present as monosodium glutamate, and about $11 \mathrm{~mm}-\mathrm{K}^{+}$added as potassium phosphate and hydroxide. For pulse-chase experiments or for provoking nutrient starvation in cultures grown in nondefined media, the cells were generally shifted to dilute Tris buffers with or without $\mathrm{NaCl}$. In order to determine the effect of these ions on cell growth, exponentially growing cells were harvested, washed and recultured either in the standard medium or in the same medium in which $\mathrm{K}^{+}$was replaced by $\mathrm{Na}^{+}$. The cells shifted to standard medium grew normally and reached stationary phase in about $15 \mathrm{~h}$, whereas those shifted to medium containing $\mathrm{Na}^{+}$in place of $\mathrm{K}^{+}$failed to reach the maximum population density even after $25 \mathrm{~h}$ but showed normal growth if the medium also contained $\mathrm{KCl}$ (not shown). Tris inhibited growth when present in standard medium, and its effect, though resembling that of $\mathrm{Na}^{+}$, could not be reversed by $\mathrm{K}^{+}$.

In order to study whether $\mathrm{K}^{+}$alone is sufficient for optimum growth, the $\mathrm{Na}^{+}$in the standard medium was replaced by $\mathrm{K}^{+}$so that the medium now contained $13.5 \mathrm{mM}-\mathrm{K}^{+}$and perhaps traces of $\mathrm{Na}^{+}$. Fig. 5(a) shows that, in the absence of $\mathrm{Na}^{+}$but in the presence of 13.5 to $33.5 \mathrm{mM}-\mathrm{K}^{+}$, the growth rate was the same as in standard medium; $\mathrm{NaCl}$ added to 1 to $10 \mathrm{~mm}$ to medium containing $13.5 \mathrm{~mm}-\mathrm{KCl}$ did not alter the growth rate (not shown), but concentrations $>10 \mathrm{mM}$ 


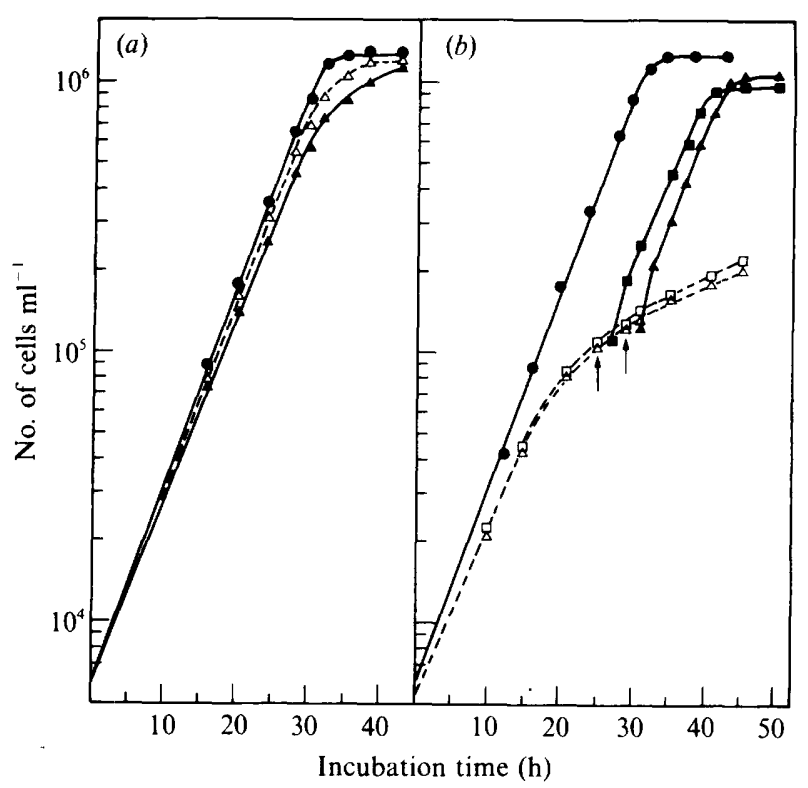

Fig. 5. Effect of different concentrations of $\mathrm{K}^{+}$and $\mathrm{Na}^{+}$on cellular growth in the standard defined medium and the obligatory requirement of $\mathrm{K}^{+}$for optimum growth. Cells of $T$. thermophila from late exponential phase cultures grown in the defined medium were harvested and washed, and recultured as follows: (a) $\mathrm{Na}^{+}$-free standard defined medium (I $\left.3.5 \mathrm{mM}-\mathrm{K}^{+}\right)$supplemented with 0,10 or $20 \mathrm{mM}-\mathrm{KCl}$ ( ; all gave the same results), or with $20(\triangle)$ or $30(\Delta) \mathrm{mM}-\mathrm{NaCl} ;(b)$ standard medium $\left(11 \mathrm{~mm}-\mathrm{K}^{+}\right.$, $\left.2.4 \mathrm{mM}-\mathrm{Na}^{+}\right)(\mathrm{O})$ or $\mathrm{K}^{+}$-free standard medium with $20(\square)$ or $30(\triangle) \mathrm{mM}-\mathrm{Na}^{+}$, or after addition of $20 \mathrm{mM} \cdot \mathrm{K}^{+}$, at the point indicated by arrow, to cultures containing $20(\square)$ and $30(\mathbf{A}) \mathrm{mM}-\mathrm{NaCl}$ alone.

retarded growth significantly. Fig. $5(b)$ shows that while $\mathrm{Na}^{+}$cannot sustain optimum growth, $\mathrm{K}^{+}$, either alone or in the presence of $\mathrm{Na}^{+}$, can. In the standard medium containing $\mathrm{Na}^{+}$in place of $\mathrm{K}^{+}$, growth was greatly retarded with less than four generations in $50 \mathrm{~h}$; however, addition of $\mathrm{KCl}$ at any stage, resulted in resumption of normal growth after $2 \mathrm{~h}$.

The results presented in this paper suggest that Tetrahymena depends on membrane transport for the uptake of nutrients from the defined medium, since in the defined medium nutrients occur as low molecular mass substrates that do not stimulate the formation of digestive vacuoles that are normally required for rapid growth (Rasmussen, 1974). The growth response to variations in culture temperature, to the nature of monovalent cations and to the concentration of amino acids present indicates that transport is not by simple diffusion but is carrier-mediated and dependent on the presence of $\mathrm{K}^{+}$. A significant observation on the regulation of growth by amino acids is that nutrient uptake as well as cell growth and proliferation are under stringent control. Interestingly, the cells manifest such a stringent response in a growing culture as soon as the concentration of even a single essential amino acid declines to a critical threshold which is insufficient to support one more doubling of the population, at which point they arrest net accumulation of both protein and RNA.

This work formed part of the research programme of CNRS Equipe de Recherche 101 directed by Dr D. H. Hayes to whom I am grateful for providing facilities and fruitful advice. I am indebted to Dr Marguerite Cuny for the invaluable discussions and constant encouragement during the course of this work and for helpful comments on the manuscript. I am thankful to Drs Leif Rasmussen and Karsten Kristiansen of Odense University, Denmark, for kindly sharing with me their knowledge and experience on the cultivation and handling of Tetrahymena. Financial support was provided by the Centre National de la Recherche Scientifique and the Fondation pour la Recherche Médicale Française. 


\section{REFERENCES}

Cameron, I. L. (1965). Macromolecular events leading to cell division in Tetrahymena pyriformis after removal and replacement of required pyrimidines. Journal of Cell Biology 25, 9-18.

Cameron, I. L. (1973). Growth characteristics of Tetrahymena. In Biology of Tetrahymena. pp. 199226. Edited by A. M. Elliott. Pennsylvania, USA: Dowden, Hutchinson \& Ross.

Cuny, M., Sripati, C. E. \& Hayes, D. H. (1985). The specific phosphorylation of a $40 \mathrm{~S}$ ribosomal protein in Tetrahymena is induced by sodium. Journal of Cellular Physiology 124, 349-357.

Elliott, A. M. (1959). Biology of Tetrahymena. Annual Review of Microbiology 13, 79-96.

Elliott, A. M., Brownwell, L. E. \& Gross, J. A. (1954). The use of Tetrahymena to evaluate the effect of gamma radiation on essential nutrients. Journal of Protozoology 1, 193-199.

ENGBERG, J. (1985). The ribosomal RNA genes of Tetrahymena: structure and function. European Journal of Cell Biology 36, 133-151.

EVERHART, L. P., JR (1972). Methods with Tetrahymena. Methods in Cell Physiology 5, 219-288.

GaLl, J. G. (1984). Ciliates come of age. Nature, London 310, 453-454.

GoRovsKY, M. A. (1980). Genome organization and reorganization in Tetrahymena. Annual Review of Genetics 14, 203-239.

HJELM, K. K. (1970). A technique for cultivation of Tetrahymena in rotating bottles. Experimental Cell Research 60, 191-198.

Holz, G. G., JR (1973). The nutrition of Tetrahymena: essential nutrients, feeding and digestion. In Biology of Tetrahymena, pp. 89-98. Edited by A. M. Elliott. Pennsylvania, USA: Dowden, Hutchinson \& Ross.

Holz, G. G., JR, ERwin, J. A. \& Davis, R. J. (1959).
Some physiological characteristics of the mating types and varieties of $T$. pyriformis. Journal of Protozoology 6, 149-156.

Holz, G. G., JR, ERwin, J., Rosenbaum, N. \& AARONSON, S. (1962). Triparanol inhibition of Tetrahymena and its prevention by lipids. Archives of Biochemistry and Biophysics 98, 312-322.

HuFSMID, J.-D. (1985). Organisation du gènome et des gènes ribobosomaux des protozoaires ciliés holotriches. Année biologique 24, 313-336.

KIDDER, G. W. \& DEWEY, V. C. (1951). The biochemistry of ciliates in pure culture. In Biochemistry and Physiology of Protozoa. vol. 1, pp. 323-400. Edited by A. Lwoff, New York: Academic Press.

OrIAS, E. \& RASMUSSEN, L. (1976). Dual capacity for nutrient uptake in Tetrahymena. IV. Growth without food vacuoles and its implication. Experimental Cell Research 102, 127-137.

Rasmussen, L. (1974). Food vacuole membrane in nutrient uptake by Tetrahymena. Nature, London $\mathbf{2 5 0}$, 157-158.

Rasmussen, L. \& Kludt, T. A. (1970). Particulate material as a prerequisite for rapid cell multiplication in Tetrahymena cultures. Experimental Cell Research 59, 457-463.

Rasmussen, L. \& Modweg-Hansen, L. (1973). Cell multiplication in Tetrahymena cultures after addition of particulate material. Journal of Cell Science 12, 275-286.

Rasmussen, L., Toftlund, H. \& SUHR-Jessen, P. (1985). Utilization of iron complexes in an animal cell. Journal of Cellular Physiology 122, 155-158.

SuHR-JesSEN, P. B. \& ORIAS, E. (1979). Mutants of Tetrahymena thermophila with temperature sensitive food vacuole formation. Experimental Cell Research 124, 317-327. 